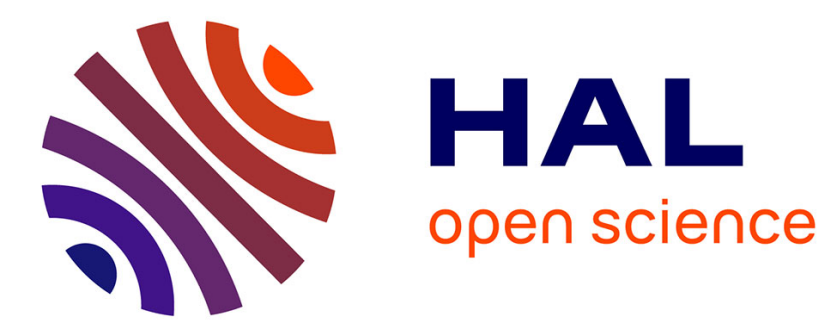

\title{
4D digital holographic microscopy
}

Alexey Brodoline, Daniel Alexandre, Michel Gross

\section{To cite this version:}

Alexey Brodoline, Daniel Alexandre, Michel Gross. 4D digital holographic microscopy. European Conference on Lasers and Electro-Optics and European Quantum Electronics Conference (CLEO), Optical Society of America, Jun 2017, Munich, Germany. pp.JSII_1_5, 10.1109/cleoe-eqec.2017.8087768 . hal-01927266

\section{HAL Id: hal-01927266 https://hal.science/hal-01927266}

Submitted on 19 Nov 2018

HAL is a multi-disciplinary open access archive for the deposit and dissemination of scientific research documents, whether they are published or not. The documents may come from teaching and research institutions in France or abroad, or from public or private research centers.
L'archive ouverte pluridisciplinaire HAL, est destinée au dépôt et à la diffusion de documents scientifiques de niveau recherche, publiés ou non, émanant des établissements d'enseignement et de recherche français ou étrangers, des laboratoires publics ou privés. 


\title{
4D Digital Holographic Microscopy
}

\author{
Alexey Brodoline, Daniel Alexandre, Michel Gross* \\ Laboratoire Charles Coulomb - UMR 5221 CNRS-Université Montpellier Place Eugène Bataillon 34095 Montpellier \\ michel.gross@umontpellier.fr
}

\begin{abstract}
Citation A. Brodoline, D. Alexandre, and M. Gross, "4D Digital Holographic Microscopy," in 2017 European Conference on Lasers and Electro-Optics and European Quantum Electronics Conference, (Optical Society of America, 2017), paper JSII_1_5.

The European Conference on Lasers and Ëlectro-Optics 2017 Munich Germany 25-29 June 2017 ISBN: 978-1-5090-6736-7 DOI: 10.1109/CLEOE-EQEC.2017.8087768

From the session Tomography and Computational Imaging (JSII_1) (invited)
\end{abstract}

4D Digital Holographic Microscopy (4D-DHM) is a new technique capable of performing 3D imaging of moving objects. 3D reconstruction is made from a single hologram, but is restricted to sparse objects that occupy only small part of the volume. For a sequence of holograms, 4D-DHM therefore performs 4D (x; y; $\mathrm{z}$ and $\mathrm{t}$ ) imaging. 4D-DHM is well suited to image micro circulation, and has been validated imaging red blood cells circulating in a zebrafish embryo in vivo [1-3].
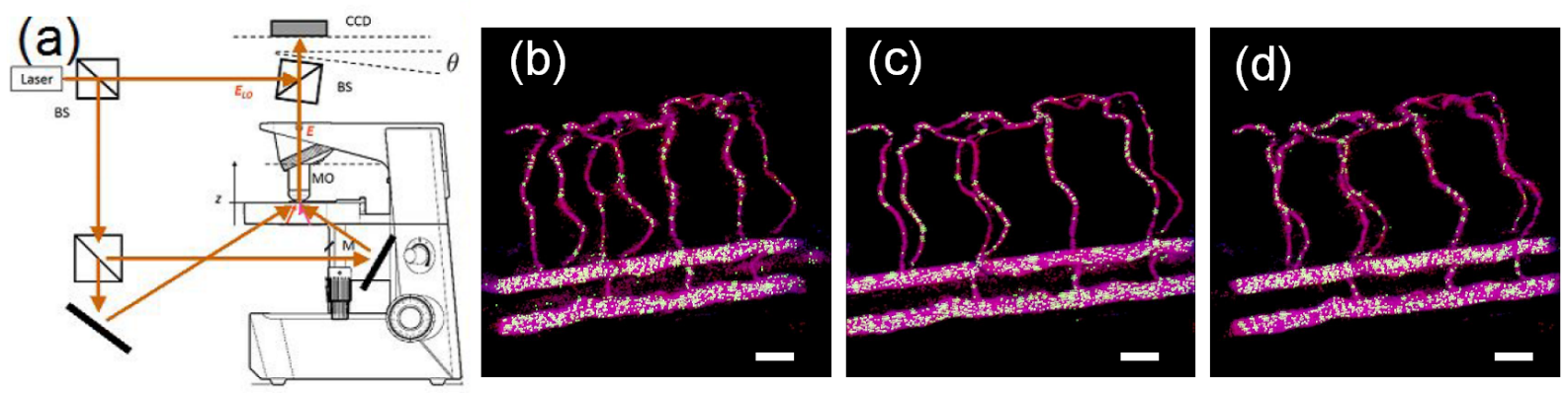

Fig. 1 (a) Holographic setup. (b, c and d) Images of blood flow within a zebrafish embryo: blood vessel (purple) and RBCs (green). The displayed 2D images correspond to the projections along $\mathrm{z}$ of the 3D images rotated along the $y$ direction by $-30^{\circ}$ (b), $0^{\circ}(\mathrm{c})$ and $+30^{\circ}(\mathrm{d})$. Bar is $50 \mu \mathrm{m}$,

The principle of the 4D DHM is illustrated by Fig. 1 (a). The setup is an upright microscope, which has been modified to perform Digital Holographic Microscopy (DHM) in transmission. The white light illumination is replaced by a laser, which is split in two beams of different directions. To perform holographic detection a reference arm $\left(E_{L O}\right.$ field) is added on the detection side. The field $E$ scattered by the object interferes with $E_{L O}$, and a camera records sequences of frames. These frames are used to calculate the holograms, and to reconstruct in 3D the field scattered by the sample. By a proper analysis of this information, 3D images of the blood vessels, and 4D images of the moving red blood cells (RBCs) can be obtained see Fig,1 (b) to (d).

To get these images, we have proceeded by the following way [2,3]. First, we calculate the holograms which differences of frames, and select by the way the signal from the moving components of the object (i.e.) the RBCs signal. We have then extract from the data, the holograms corresponding to the two illumination. For each RBC, and each illumination, the field that can be reconstructed by holography as a narrow cone of light (narrow because RCBs are much larger than the wavelength), which is angularly tilted like the illumination. The location of RBCs is then obtained by considering the intersection of the two cones. To prevent the signals of the different RBCs to mix together, the positions of the RBCs that give the largest signals are calculated first. The contributions of these RBCs are then removed from the hologram, and the positions of the following RBCs are calculated from the hologram thus cleaned.

The reconstruction by cleaning is highly non-linear (unlike conventional holographic reconstructions), since it is the algorithm that decides to place a RBC in a plane and to remove the field diffused by this RBC from the other planes. In order to converge successively it requires to image sparses objects, that occupy only small part of the holographic reconstructed volume. 4D-DHM is thus capable of performing 3D reconstruction is made from a single hologram, but is restricted to sparse objects that occupy only small part of the volume. 
We acknowledge Labex Numev (convention ANR-10-LABX-20) for funding.

\section{References}

[1] Verrier, N., Alexandre, D., \& Gross, M. (2014). Laser Doppler holographic microscopy in transmission: application to fish embryo imaging. Optics express, 22(8), 9368-9379

[2] Brodoline, A., Donnarumma, D., Alexandre, D., \& Gross, M. (2016, July). 4D Holographic Reconstruction of Embryonic Blood Flow by Greedy Algorithm. In Digital Holography and Three-Dimensional Imaging (pp. DTh1E-1). Optical Society of America.

[2] D. Donnarumma, A. Brodoline, D. Alexandre, and M. Gross. 4d holographic microscopy of zebrash larvae microcirculation. Optic Express 24(3):26887-26900, 2016 